\title{
ANTI-CORRUPTION AGENDA FOR STATE GEOCADASTRE OF UKRAINE BY 2030 IN THE CONTEXT OF TRANSPARENCY OF PUBLIC FINANCE
}

\author{
Denys Pudryk ${ }^{1}$, Yaryna Bohiv ${ }^{2}$, Nataliia Shpak ${ }^{3}$
}

\begin{abstract}
"Corruption is hidden where there is no transparency of finances. And while there is even the slightest opportunity to bypass the system, it will be used...». Jose Ugaz, a former prosecutor for Peru who chaired Transparency International in 2014-2016, Board Member of TI Ukraine
\end{abstract}

\begin{abstract}
The present article concentrates on analyzing the ways of increasing efficiency of transparency of public finances reduced of broader significance: from the analysis of the quality of the state and local management in the social, environmental sphere. In this article, we discuss interlinkages between corruption, transparency of public finances, and the value of technological developments in the context of the 2030 Agenda for Sustainable Development. The main purpose of this article is to characterize the legal and economic basis for ensuring transparency of public finances to monitor the effectiveness of their distribution, which becomes crucial for the success of the reform process in all areas of the national economy. The authors emphasized the importance of the impact of trends in the political-legal environment, the economic and financial sphere on the transformation of the state anti-corruption strategy. A review of gaps in anti-corruption legislation is essential for effective practices combating corruption. Present status and theoretical results of the formation and implementation of SDG 16 in the legislation of the state anti-corruption strategy contradictory are summarized. The practical significance of the research results is to formulate a hypothesis, the essence of which lies in the new knowledge about overcoming corruption in the process of dynamic transformation through the integration of SDG 16 into the National AntiCorruption Strategy and enhancing transparency of public finances by digital technologies as a prerequisite for achieving all other development goals on the 2030 Agenda for Sustainable Development. This hypothesis aims to change the strategic directions and directions in economic policy-making in order to neutralize the harmful processes of corruption. The value of the results obtained in contemporary research is driven by the transnational nature of the phenomenon of corruption and its relation to other harmful processes that are produced in the economic space and lead to the institutionalization of the global economic crisis. Methodology. A holistic approach is used to analyze both the extent and causes of corruption in Ukraine by looking at the system of checks and balances and institutional pillars that form a society, including the executive, legislature, judiciary, and civil society.
\end{abstract}

Key words: corruption, increasing efficiency, transparency, public finances, illicit financial flows, the 2030 Agenda for Sustainable Development, national economy.

JEL Classification: R52, D73

\section{Introduction}

Despite the high level of corruption in Ukraine, the ability to manage large data sets in the field of public finance is designed to identify conflicts of interest, potential, current, and cases of inefficient allocation of resources. At the same time, transparency of public finances comes not more from the analysis of budget indicators, but in a broader sense: from the analysis of the quality of government management and local government in the social, cultural, environmental sphere.

Corruption is the biggest obstacle to achieving the Sustainable Development Goals (SDGs) in Ukraine.

\footnotetext{
Corresponding author:

${ }^{1}$ University of the State Fiscal Service of Ukraine, Ukraine.

E-mail: pudrik.nusta@ukr.net

${ }^{2}$ Lviv Polytechnic National University, Ukraine.

E-mail: yaryna bohiv@ukr.net

${ }^{3}$ University of the State Fiscal Service of Ukraine, Ukraine.

E-mail: shpak2006@ukr.net
} 
Ukraine, like the other UN member states, joined the global process of sustainable development. The process of adaptation of the SDGs, initiated to create a strategic basis for Ukraine's national development for the period up to 2030, was initiated (Sustainable Development Strategy for Ukraine by 2030, Draft, 2017).

Corruption exacerbates inequality and limits participation and representation of vulnerable groups in decision-making processes at all levels. Not only exclusion and discrimination violate human rights, but it also causes outrage and hostility, and can lead to violence. Anti-corruption strategies that empower vulnerable and marginalized groups to access information, promote merit-based recruitment and promotion and facilitate equal participation at all levels, not only promote inclusion but also allow people to express concern and demand accountability (Tylchyk V., Tylchyk O., 2019).

Corruption undermines the ability of the justice sector to remain independent, integral and accessible. This means that conflicts remain unresolved and people cannot receive protection. Institutions that do not function in accordance with legal laws are prone to arbitrariness and abuse of power and are less able to provide public services to anyone.

Strengthening transparency, accountability and integrity in the justice sector and relevant institutions can thus enable these agencies to legally perform their functions and gain public confidence. Corruption destroys trust in government agencies, undermines the rule of law and impairs the system of checks and balances. They have a strong influence and pose a serious threat to peace and security.

Corruption helps to create a climate for conflict to flourish. The links between corruption, human rights abuses, violent extremism, impunity, trafficking in human beings and illicit financial flows have repeatedly been recognized by the UN Security Council and the General Assembly as serious challenges to achieving sustainable development, peace and security.

Thus, there is a growing understanding that challenges to corruption and governance must be addressed as an integral part of conflict situations, from prevention to peacebuilding, and failure to do so will lead to further risks of conflict and instability.

\section{Understanding aspects of sustainable development}

Five critical aspects are at the heart of the 2030 Agenda, people, prosperity, the planet, partnership, and peace. Traditionally, it is due to the prism of three key elements: social inclusion, economic growth, and the environment, but the concept of sustainable development becomes more important with the adoption of the 2030 Agenda, based on the traditional approach, adding two critical components: partnership and peace. Real sustainability lies in these five dimensions.
The 2030 Agenda inspires us to think creatively, use innovative approaches, and critically rethink how we approach today's challenges.

The Sustainable Development Goals are comprehensive, complex and interconnected. Due to their synergistic nature, the implementation of the 2030 Agenda for Sustainable Development renewed interest in national development strategies. However, most national strategies detail how they will be funded. Mobilizing sufficient resources remains a key challenge.

Member States of the United Nations have recognized this challenge in the Addis Ababa Action Agenda. They decided to create integrated national funding frameworks to support their sustainable development strategies. Such country-specific funding frameworks integrate funding and related policies that are most relevant to addressing country financing issues. They look at the full range of funding and non-financial resources available to countries and have developed a financing strategy to attract resources, manage risk and achieve sustainable development priorities. In short, the integrated national funding framework is a tool for the implementation of the Addis Ababa Action Agenda at the national level.

There are several advantages to an integrated approach. Combining funding and related policy with long-term goals, integrated funding frameworks can help overcome short-term-focused solutions.

Adopting integrated national funding mechanisms is challenging. In many countries, opportunities are limited and policy reform is expensive; long "tasks": therefore, the lists of necessary reforms will not help. Existing funding policies can be biased due to serious political constraints that cannot be ignored. However, there are many elements that countries can rely on.

All countries have different fiscal policies. If they have already embarked on a national sustainable development strategy, they should also create governance and coordination mechanisms. An integrated funding structure will not have to reinvent the wheel; it is a tool for identifying and implementing targeted policies and reforms to improve their effectiveness, coherence, and relevance to sustainable development. Obviously, there is an opportunity to do this in both developed and developing countries.

Each global task was considered taking into account the specifics of national development. National SDGs will form the basis for joint efforts to ensure economic growth, social justice, and environmental management.

The Sustainable Financing Report (2019), is intended to guide the Member States in developing and implementing integrated national financing mechanisms. The four main blocks of their practical implementation are presented: evaluation and diagnostics; development of financing strategy; monitoring, review and accountability mechanisms; and management and coordination mechanisms. 
As an interest in more integrated and strategic approaches to sustainable development financing will become more detailed lessons for their development and implementation. These lessons form the basis of the analysis suggested in this chapter and will serve as a guide for the Inter-Agency Task Force on Financing for Development (IATF) as it continues to refine its methodology and work in this area, such as further developing the policy tools that are most relevant and useful for different countries (Sustainable Development Financing Report, 2019).

\section{Solutions for financial stability}

The obvious weakness of the state is tax evasion and theft; less trust in government, state institute; lower income for the state; poor quality of public services: education, health care, public transport, etc.

The IMF Financial Transparency Code (Code) is the international standard for disclosure of public finances. The 2014 Code includes a set of principles based on four fundamental principles:

Fiscal Reporting (Component I). Fiscal reporting should include a comprehensive, up-to-date, timely and reliable overview of the financial position and performance of the government.

Fiscal Forecasting and Budgeting (Component II). Budgets and related budget forecasts must contain a clear statement of the government's budgetary goals and political intentions, as well as comprehensive, timely and accurate public finance forecasts.

Fiscal Risk Analysis and Management (Component III). Governments should identify, analyze and manage risks to public finances and ensure effective coordination of public sector budget decisions.

Resource Revenue Management (Component IV). Governments must provide a transparent framework for ownership, contracting, taxation and use of natural resources (Budget Transparency Tool, 2014).

To implement the 2030 Agenda for Sustainable Development and fulfil the commitments of "not leaving anyone behind", the collection, processing, analysis and dissemination of outstanding volumes of data, including general data, for effective policy development, as well as for monitoring and assessment of progress, are performed. On the Agenda, it was decided to ensure international cooperation, including through technical and financial support, to further strengthen the capacity of national statistical offices and national statistical systems. Given the growing need for shared data, as well as the opportunities and challenges faced by unconventional data sources, providers should strengthen their support for the statistical systems of developing countries by improving the capacity building. National Strategies for the Development of Statistics (NSDS) provide a common vision for the development of national statistical systems and solve problems related to the integration and use of data from various sources, as well as the development of statistical potential. To ensure compliance with national priorities, statistical strategies should be closely linked to national sustainable development strategies and connected with an integrated financial framework.

Big data is an opportunity to complement traditional sources of statistical information to measure progress towards the Sustainable Development Goals (SDGs) and to increase focus on political efforts but it presents new risks and challenges. The international community should work to develop technical standards that adequately govern data access, data privacy, and security while continuing to comply with applicable statistical quality standards.

Efforts are continuing to improve the collection and dissemination of financial sector data and financial vulnerability. At the second stage of the G20 Gap initiative, progress was made in monitoring shadow banks, reporting on globally important systems and improving the coverage, timeliness, and frequency of work of sector banks. Accounts. It is important to provide adequate resources to support the necessary access and data infrastructure and to further service the newly created DGI datasets.

To address the negative impact of corruption on human rights, a human rights-based strategy places international human rights and claims (of copyright holders) and relevant government bonds ("tariffs") at the centre of the discussion on corruption and efforts at all levels. It also brings together international principles in the field of human rights, including nondiscrimination and equality, participation, inclusion, accountability, transparency, etc.

Illegal financial flows describe the movement of money that was illegally acquired, transferred or spent across borders. The sources of these cross-border transfers come in three forms: corruption, such as bribery and theft of government officials; criminal acts, such as drug trafficking, human trafficking, illegal sale of weapons, etc. and tax evasion and unjustified transfers.

The World Economic Forum estimates that 2 trillion USD spent on corruption each year can eliminate hunger ( 116 billion USD), eliminate malaria ( 8.5 billion USD in 7 years), bridge the global infrastructure gap ( 1 trillion USD) and provide basic education for all children (26 billion USD). Effective anti-corruption measures can help open up significant levels of development funding (Thomson, 2017).

The volume of illegal financial flows is huge. They have a major impact on the global economy, destroying poor countries and have a clear link to corruption. Confidentiality plays an important role in obtaining illicit financial flows. Governments should establish compulsory public records that reveal beneficial ownership of trust funds and companies in order to more easily track illicit financial flows and make it easier 
for people to earn income from corruption and criminal proceeds.

This framework was developed by Transparency International and is useful for assessing a country's strengths and weaknesses and for developing an anticorruption strategy.

Developing democracies, such as Ukraine, can benefit from the best practices of developed countries. For example, according to Steinmo (2018), Sweden, which has become a strong tax bracket, is not because it has more economic resources than in other countries, but through the process of experimentation and adaptation of innovative means of resource extraction. Inventory and population registers formed the basis for Sweden's monitoring capabilities, which included tax benefits. The development of the twentieth century strengthened but did not create the main forces that served the state. Improving monitoring capabilities has been the latest in a long history of innovation when the state needed to provide the information necessary to tackle collective tax measures. The welfare state, which was created to provide services in exchange for high taxes, continued the tradition of a robust vertical tax treaty between the state and citizens.

The current state of taxation in Sweden is as exceptional as in the previous current state of taxation. The modern tax state supports high fiscal monitoring potential and strong vertical and horizontal fiscal agreements. Although it is no longer controlled mainly by war, the current tax situation has won and continued its financial alienation.

Digital technologies provide innovative tools for tracking government money in real-time, as technologies become key in the fight against corruption. New technologies and big data open up new perspectives for oversight by government and stakeholders and help control prevention methods and even predict corruption. This has been hidden in the past through paper-based nontransparent practice.

In particular, after possible decisions by Manal Found and other (2019), the following technical developments can be considered:

- the distributed core technology, for example, Blockchain, for proper design and processing, allows you to safely and openly store personal information and transaction information. They can increase accountability and reduce vulnerability to corruption in government operations by increasing the integrity of data records and the reliability of publicly available information;

- an increasing number of countries provide open access to government agency data in a machine-readable format, allowing users to research, analyze and reuse it. This can increase transparency and accountability, for example, by showing where and how public money is spent. Big datasets can also be analyzed to help identify patterns of potential corruption;
- machine learning and artificial intelligence (AI) can reveal patterns and practices that are too complex for humans to detect. AI can process large amounts of data and quickly identify patterns that may indicate potentially corrupt behavior.

\section{Conclusion}

To counter this negative phenomenon (corruption), it is necessary to include SDG 16 in the Ukrainian national anti-corruption strategy as a prerequisite for achieving all other development goals on the 2030 Agenda for Sustainable Development. It will provide a framework for demanding better governance and increased accountability.

The need to urgently create the 2030 Anti-Corruption Agenda for Sustainable Development in the 21st century world imperatives, with many of these goods already in danger of exhaustion or irreversible degradation or generating disasters and calamities (expansion of the desert areas, following massive deforestation, expansion of agricultural areas, at the cost of irreversibly damaging the ecosystems of tropical forests, resources of drinking water, air quality in great industrialized cities, transborder pollution of the great rivers or lakes, lessening and pollution of aquatic food resources (species of fish), pollution of the marine and oceanic ecosystems, endangering biodiversity, massive and uncontrolled flooding of the great watercourses, on account of the massive deforestation and land mafia, etc.).

The connection between the objectives of durable development at a global level and environmental protection must be a priority in terms of the nature and size of the duties assumed by these institutions. Thus, they must take into consideration the protection of natural resources, for their optimal use by the future generations, ensuring a global framework for living, with improved standards, in comparison to standards of the 20th century, ensuring the development of material and spiritual values, the necessity to ensure the preservation and protection of natural ecosystems, the need for rational, moderate use of natural resources, the need to change the civilization model (from an industrial one to a model of green and renewable energy), the need to maintain the biodiversity and to prevent the various forms of trans-border pollution, to prevent the negative effects of the natural phenomena, to adopt non-polluting technologies at a large scale, up to a global level of use, to recover and recycle usable residual substances, to encourage cooperation in multiple domains, among the states and the non-state actors transnational corporations, in particular, to protect the environment.

Promote land use planning and efficient spatial concentration: the spatial concentration of urban areas is a unique characteristic that enables the real scale of economies, efficient delivery of services, and effective use of amenities. 
In Ukraine, the problem of interoperability of open databases still not solve. Thus, there is a necessity to compare spatial data with data from taxpayers and registers, land cadastre, urban cadastre, State Register of Real Estate Rights, financial reporting data, statistics, permits for the use of natural resources and others, primarily in relation to illegal deforestation, extraction of natural resources and land use agricultural purpose.

\section{References:}

Budget Transparency Toolkit International Standards List of Standards IMF (2014). Retrieved from: http://www.oecd.org/governance/budget-transparency-toolkit/international-standards/list-of-standards/imf/ (accessed 18 January 2020).

Financial stability board (2017). Fiscal Transparency Code. Retrieved from: https://www.fsb.org/2017/11/fiscaltransparency-code/ (accessed December 2019).

Financing for Sustainable Development Report (2019). Retrieved from: http://developmentfinance.un.org (accessed 18 January 2020).

Jose Ugaz (2019). Koruptsiya khovayet'sya tam, de nemaye prozorosti finansiv [Corruption is hidden, it does not have financial transparency]. TI Ukraine. Retrieved from: https://ti-ukraine.org/blogs/koruptsiya-hovayetsya-tam-denemaye-prozorosti-finansiv/ (accessed 15 December 2019).

Manal Found and other (2019). Enhancing Governance in Public Finance: The Role of Data and Technology. Retrieved from: https://imfilab.brightidea.com/ct/h.bix?c=8746D5CB-E6CB-11E9-8AD2-0E86B03ECB0E (accessed 18 January 2020).

Stratehiya staloho rozvytku Ukrayiny do 2030 roku Proekt - 2017 [Draft Sustainable Development Strategy of Ukraine to 2030 and National Action Plan to 2020 for the implementation of the Strategy - 2017]. United Nations Development Program in Ukraine. Retrieved from: https://www.undp.org/content/dam/ukraine/docs/ SDGreports/UNDP_Strategy_v06-optimized.pdf (accessed 15 December 2019).

Sven H. Steinmo. The Leap of Faith (2018). The Fiscal Foundations of Successful Government in Europe and America. The United Kingdom Oxford University Press is a department of the University of Oxford.

Thomson, S. (2017). We waste $\$ 2$ trillion a year on corruption. Here are four better ways to spend that money. Retrieved from: https://www.weforum.org/agenda/2017/01/we-waste-2-trillion-a-year-on-corruption-here-arefour-better-ways-to-spend-that-money/ (accessed 28 January 2020).

Transforming our world: the 2030 Agenda for Sustainable Development. United Nations. A/RES/70/1. Retrieved from: https://sustainabledevelopment.un.org/content/documents/21252030\%20Agenda\%20for\%20 Sustainable\%20Development\%20web.pdf (accessed 18 January 2020).

Transparency International the global coalition against corruption. Anti-corruption glossary. Retrieved from: https://www.transparency.org/glossary/term/illicit_financial_flows (accessed 15 December 2019).

Bielai, S., Morozov, I., \& Tylchyk, V. (2018). The innovative approach to the crisis situations monitoring of the social and economic origin that endanger the security of Ukraine. Baltic Journal of Economic Studies, vol. 4, no. 3, pp. 15-21. doi: 10.30525/2256-0742/2018-4-3-15-21

Jankovska, L., Tylchyk, V., \& Khomyshyn, I. (2018). National economic security: an economic and legal framework for ensuring in the conditions of the European integration. Baltic Journal of Economic Studies, vol. 4, no. 1, pp. 350-357. doi: 10.30525/2256-0742/2018-4-1-350-357

Tylchyk, O., Pluhatar, T., \& Kotukha, O. (2018). Determinants of shadowing of the economy: the genesis of economic and legal doctrines. Baltic Journal of Economic Studies, vol. 4, no. 3, pp. 302-308. doi: 10.30525/22560742/2018-4-3-302-308

Tylchyk, O., Dragan, O., \& Nazymko, O. (2018). Establishing the ratio of concepts of counteraction to legalization (laundering) of illegally-obtained income and counteraction to the shadow economy: the importance for determining performance indicators of the European integration processes. Baltic Journal of Economic Studies, vol. 4, no. 4, pp. 341-346. doi: 10.30525/2256-0742/2018-4-4-341-345 